\title{
Enhancing Extreme Weather Early Warning Systems in Upper Bekasi River Basin Through Coupled Hydro-meteorological Model
}

\author{
Nizam Mawardi ${ }^{1}$, Chay Asdak ${ }^{2}$, and Rista Hernandi Virgianto ${ }^{3}$ \\ ${ }^{1}$ Environmental and Energy Management Program, University of Twente, The Netherlands \\ ${ }^{2}$ Centre for Environment and Sustainability Science, Padjadjaran University, Indonesia \\ ${ }^{3}$ State College of Meteorology, Climatology, and Geophysics, Indonesia
}

\begin{abstract}
Flooding is frequently emerging events in the Upper Bekasi river basin and causes economic loss, property damage, loss of life, and even hinders sustainable development. Torrential rain is one of the natural hazards that often triggers flooding, especially in watersheds that have undergone land use changes. One of the mitigation efforts that can be carried out by the vicinity community, government, private enterprises and other stakeholders is by utilizing an early warning system. This study will delineate the successful use of coupled hydro-meteorological models to predict flooding in various regions of the world with different climatic and terrestrial characteristics. However, in order for an early warning system to be effective and improve community resilience, four vital elements of early warning systems are recommended to be fulfilled, namely risk knowledge, monitoring and warning services, dissemination and communication, and response capability. Therefore, this study will compile how coupled hydro-meteorological model is utilized properly to generate an effective early warning system so that thriving sustainability can be achieved.
\end{abstract}

\section{Introduction}

Indonesia is an archipelagic country that is known as the Indonesian Maritime Continent (IMC) has heavy rainfall due to high evaporation rates, specifically when the Southeast Asian Monsoon [1]. In the future, however, extreme weather events are projected to rise per global warming [2]. Including Indonesia, evident indices of widely rising temperature and increasing wetter conditions are observed [3]. Deforestation in a tropical environment that change the land-use and land cover result in increases of precipitation and surface temperature [4]. Reciprocally related events, the flood is a combination of the meteorological and hydrological type of disasters. Roughly speaking, short-term atmospheric processes such as torrential rain and storm become precedent to overflow of bodies of water that inundated not only human residential neighbourhoods but also natural habitats. In recent years, hydrological and meteorological calamities account for more than $80 \%$ of disaster occurrences across the globe [5]. Furthermore, Asdak et al. [6] explained that peak floods are increased due to the depletion of forested areas in the upper watershed. Particularly in flood-prone areas that are developed, therefore, flooding events and their exposure are recorded increasing over time [7].

One of the flood-plain areas in Indonesia is its capital megacities of Jakarta and its surrounding. Flooding events in Jakarta caused hundreds of million dollars of economic loss annually, hundreds of thousands of residents were displaced, and hundreds of lives were lost [7, 8]. Likewise, the Upper Bekasi river basin that flows close to the border of Jakarta through Bogor Regency and Bekasi city is one of the river basins that have undergone remarkable land-use changes. According to Kadri et al. [9], there are significant changes in a hefty $43 \%$ of forested areas that become built-up areas between 1990 and 2018. Hence, these anthropogenic activities result in the intensification of runoff peak discharges that may cause flooding. Crucially, the increase of flood events will lead to more losses of the economy and even lives, damages of properties, and hamper sustainable development.

The downstream of the Upper Bekasi river basin is one of the areas that deeply inundated (approximately 2 $-3 \mathrm{~m}$ ) during the frequent flood [10]. This area is the confluence of two tributaries, namely the Cikeas sub river basin and Cileungsi sub river basin (see Fig 1). Grievously, according to the Indonesian Agency for Meteorology, Climatology, and Geophysics (abbreviated as BMKG) that has the responsibility of weather monitoring and forecasting, there has been extreme torrential rain in the early of 2020 that the highest rainfall recorded is $377 \mathrm{~mm}$. BMKG asserted that this event was the highest rainfall in more than a hundred years. The enormous precipitation began to occur on 31st December 2019 until 1st January 2020. This extreme weather event might cause the perforation of the dikes at the Cikeas sub river basin, so the overflow inundated and accounted for the loss of 9 lives [11]. 
One of the countermeasures to down casualties because of flooding is effective warning systems (EWSs). An effective EWS is a warning system that should empower people and stakeholders to take appropriate responses to natural hazards. Furthermore, an effective EWS encompasses four key elements, namely risk knowledge, monitoring and warning service, dissemination and communication, and response capability [12]. On the one hand, an initial step to perform proper responses is generating timely and accurate weather forecasts [13]. Therefore, a sufficient two-day lead time for societies to take decent actions can be provided by numerical weather prediction (NWP) that can generate detailed two-days in advance weather forecasts [14]. According to Powers et al. [15], to predict the weather, NWP that is used mostly throughout the world is Weather Research and Forecasting (WRF). Even though the WRF is reliable to be harnessing at forecasting floods in several watersheds [16], Senatore et al. [17] stated that a coupled hydrometeorological model the WRF-Hydro is better at predicting precipitation and soil moisture. Moreover, Sun et al. [18] upheld that WRF-Hydro has the potential capability to be operationally employed to forecasting floods. Hence, this study has the first objective to delineate the uses of WRF-Hydro across the globe in predicting precipitation and floods through literature reviews.

On the other hand, however, an effective EWS comprise four vital components that have to be achieving. Improvement of the weather forecasts is part of the monitoring and warning service element. To be effective, EWSs should promote the response of the vulnerable communities in adequate time and in the right ways to minimize property damages, the likelihood of being injured, and casualties, hence people-centred EWS is required. People-centred EWS involves more than solely accurate weather forecasts that are producing promptly. More importantly, institutional governments have the responsibility to ensure that generated warnings are delivered and understood by vulnerable residents. Therefore, the second objective of this review is to propose an EWS framework that applies four primary elements to increase the effectiveness of severe weather and flood early warning systems that thriving sustainability and resilient community can be obtaining.



Fig 1. Upper Bekasi River Basin
The results of this study started with reviews on how WRF-Hydro is employed. Subsequently, this review would discuss multidisciplinary approaches to building a suggested EWS framework in the Upper Bekasi watershed.

\section{Theoretical framework}

Developing an effective EWS is essential to achieve resilience in communities, particularly against frequent extreme weather events that may consequence in flooding. Therefore, an EWS should be people-centred that accommodate the needs of end-users, delivered timely, and understood by those at risk. In 2006, the United Nations International Strategy for Disaster Reduction (UNISDR) had established four key elements to build a people-centred EWS that promote hazard mitigation in a sufficient time.

Following UNISDR, the Indonesian national level institution for disaster countermeasure National Agency for Disaster Management (abbreviated as BNPB) adopted the main principles of effective EWS as documented in as Guidelines of Community-based Early Warning System [19]. In this guideline, key elements of effective EWS were being interpreted as:

1. Risk knowledge

The risk will emerge due to the combination of hazards and vulnerability in specific areas. Therefore, collecting data and analysing it are prerequisites to motivate people to take proper responses to natural hazards. Multiples of risk studying and mapping are the main activities in this element.

\section{Monitoring and warning service}

Warning services are regarding as the chief of the system. BNPB emphasized that there should be robust science-based knowledge to predict the occurrence of natural hazards. Moreover, 24-hours continuous monitoring on the precedents of natural hazards should take place. Additionally, the impacts of those hazards should be communicated and coordinated through existing networks.

3. Dissemination and communication

BNPB highlighted that warnings have to reach vulnerable people. Hence, identifying communication level and forming the authority to respond to the risks should be developed. This system hopefully can ensure that as much as possible vulnerable people get warned. 4. Response capability

Appropriate actions that need to be executing when natural hazards occur can be implemented through response education by disaster management institutions. On top of that, changing vulnerable people's behaviour is essential to shape robust preparedness. Besides that, escape routes also should be available before natural hazards occurring.

These principles of effective EWS adopted by BNPB have to be involving a multitude of stakeholders diverse from the local and national level of institutional governments, private sectors, and local communities. This guideline, however, encompasses all of the natural hazards. Thus, this study focused on extreme weather 
events that may induce flood where the primary actors for the EWS needed are BMKG and BNPB.

\section{Methods}

A systematic literature review of all available physical and social science literature on the employment of WRF-Hydro to various purposes in several countries and continents also practices of EWS was performed in October 2020. Criteria for inclusion in the peerreviewed review included Literature and peer-reviewed publications provided by respected or authoritative organizations such as the World Meteorological Organization (WMO) and United Nations Office for Disaster Risk Reduction (UNDRR) published in English. Literature searches were established in a variety of electronic databases, including Scopus, Springer, American Meteorological Society, European Geoscience Union, MDPI, and Web of Science. The scientific journal articles were searched in October 2020 using pre-identified keywords, including extreme weather; early warning system; floods; sustainability; and specific terms of WRF-Hydro and disaster risk management. Subsequently, assessments were conducted on the founded papers, then some of those papers that explain the employment of WRF-Hydro for various purposes were elected. Finally, those papers about WRF-Hydro were summarized and articles that described the main elements of an effective EWS were presented as the proposed framework.

\section{Results}

\subsection{Study Area}

Bekasi river basin consists of two main parts namely the upper river basin and downer river basin. This study focused on the Upper Bekasi watershed that flowing through Bogor Regency and ending in the Bekasi river. There is two large sub river basin in the Upper Bekasi watershed, namely Cikeas sub river basin and Cileungsi sub river basin. These sub river basins converge downstream of the main river basin. The watershed area covering 39.045 ha extending from Bogor Regency, Bekasi City, and Bekasi Regency. The annual temperature of the watershed is around $32^{\circ} \mathrm{C}$ and the annual rainfall is about $3.210 \mathrm{~mm}$ [9]. The annual temperature of the watershed is around $32^{\circ} \mathrm{C}$ and the rainfall of the watershed is about $3.210 \mathrm{~mm}$ per year [9]. The land-use type of the watershed area is built-up areas, forests, agriculture, and water body.

\subsection{The WRF-Hydro and its Employment}

One of the newly developed features in the WRF application in hydrological modelling by utilizing terrestrial and high-resolution hydrological data that can be running in a way that is soundly combined or paired with the WRF itself and the stand-alone capability, namely, WRF-Hydro [20]. WRF-Hydro has several capabilities to simulate geophysics, including the process of interaction between the atmosphere and the land, and the streamflow from the channel, so WRFHydro can predict streamflow directly from the future atmospheric condition in a region [21]. WRF-Hydro is a model developed by the National Oceanic and Atmospheric Administration (NOAA) and the National Weather Service (NWS) with several other agencies that are employed to predict flooding and streamflow which is used nationally in the United States as the National Water Model (NWM) [22]. This capability of WRFHydro is mostly because WRF-Hydro operates Noah's land surface modeling (originally called Noahdistributed in 2003) which can quantify the increasing complexity of the terrestrial state, provide a physically consistent ground flux, and provide drain flow information for hydrometeorological research [23].

This study briefly described the utilisation of WRF-Hydro in many continents of the world ranging from Asia, America, Africa, and Europe. Because WRFHydro is a state-of-the-art application, the initial times it was employed in 5 bygone years by Yucel et al. to forecasting flood in Turkey. In relatively short times, WRF-Hydro is employed to diverse impetus extending from calculating water balances, analysing extreme weather events, evaluating water and energy cycle, managing water resources, reconstructing streamflow, and forecasting floods. From these studies, it is evident that WRF-Hydro is reliable hydro-meteorological modelling because it generated worthy simulation and produced sound soil moisture attributes, reduced some biases and errors compare to conventional WRF, and scored decent correlation with real observation values. However, the model is remained flawed by producing a couple of errors and underestimate predictions. Regardless of some weaknesses, WRF-Hydro can be potentially employed for operational forecasting. Therefore, it is worth noting that this hydrometeorological modelling is a favourable predictor of extreme weather events and their secondary impact such as flooding in the Upper Bekasi river basin. The summary of the employment of the WRF-Hydro is showing in Table 1.

Table 1 Summary of WRF-Hydro employment

\begin{tabular}{|c|c|c|c|c|}
\hline Authors & Year. & Locations & Purposes & Resultar \\
\hline $\begin{array}{l}\text { Kerandi et al. } \\
{[24]}\end{array}$ & 2018 & Kenya & Water balances & $\begin{array}{l}\text { Undereatimate prediction } \\
\text { with tolerable NSE }\end{array}$ \\
\hline $\begin{array}{l}\text { Daabilet al. } \\
{[25]}\end{array}$ & 2017 & Ghana & $\begin{array}{l}\text { Water ressurces } \\
\text { management }\end{array}$ & $\begin{array}{l}\text { High values of NSE and } \\
\text { Pearsan's serselation. }\end{array}$ \\
\hline $\begin{array}{l}\text { Ferschet al. } \\
{[26]}\end{array}$ & 2019 & Germany & $\begin{array}{l}\text { Begional water } \\
\text { and enerox cycle } \\
\text { evaluation }\end{array}$ & 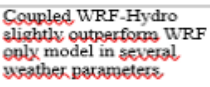 \\
\hline $\begin{array}{l}\text { Webbe et al. } \\
{[27]}\end{array}$ & 2018 & $\begin{array}{l}\text { United Arab } \\
\text { Emirates }\end{array}$ & $\begin{array}{l}\text { Extrempe weathex } \\
\text { event analusisis }\end{array}$ & $\begin{array}{l}\text { Reduction in RMSE and } \\
\text { uBLAS, compare to } \\
\text { gtandalone WRF. WRF- } \\
\text { Hydro depicted aoil } \\
\text { moisture reagengbly well }\end{array}$ \\
\hline Jersiet al. [28] & 2017 & Itakx & $\begin{array}{l}\text { Reconstruction of } \\
\text { river oupeff }\end{array}$ & 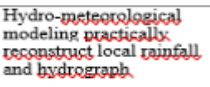 \\
\hline Rxu et al. [29] & 2017 & $\begin{array}{l}\text { Southem } \\
\text { Eorea }\end{array}$ & $\begin{array}{l}\text { Flash flood } \\
\text { forecasting }\end{array}$ & $\begin{array}{l}\text { The petential use of } \\
\text { WRF-Hydiro in flash } \\
\text { flood foxescastive } \\
\text { ipduced by beavx aja }\end{array}$ \\
\hline $\begin{array}{l}\text { Yucel et al. } \\
\text { [30] }\end{array}$ & 2015 & Iurkey & Flood forecasting & $\begin{array}{l}\text { WRF-Hydro skillfully } \\
\text { ceproduced brodreestapbs, } \\
\text { notably sxith data } \\
\text { aesimilation }\end{array}$ \\
\hline $\begin{array}{l}\text { Yaulas et al. } \\
\text { [31] }\end{array}$ & 2019 & Greece & $\begin{array}{l}\text { Flash flood } \\
\text { owabsis }\end{array}$ & $\begin{array}{l}\text { The petential benefit of } \\
\text { high-resalution } \\
\text { observation as forcing in } \\
\text { precipitation simulation }\end{array}$ \\
\hline $\begin{array}{l}\text { Axolig et al. } \\
{[32]}\end{array}$ & 2019 & Italx & Flood forecseting & $\begin{array}{l}\text { WRF-Hydro produced } \\
\text { decent yimulations of } \\
\text { vainfall and bydrologigal } \\
\text { impact }\end{array}$ \\
\hline
\end{tabular}




\subsection{Existing Early Warning Systems in Indonesia}

Multi natural hazards are threatening the archipelagic country like Indonesia. Seismic hazards that cause earthquakes and tsunami, extreme hydrometeorological events, coast and pluvial flooding, volcanic eruptions, and forest fires are the common natural hazards in Indonesia. These hazards are being the responsibility of a multitude of ministries, so coordination hindrances frequently occur. Therefore, BNPB that has the responsibility of disaster management has the capacity to curb this problem by acting as a leader and provider of multi-hazard early warning systems [19]. Under the coordination of BNPB, $\mathrm{BMKG}$ has the responsibility to predict and inform the potential of extreme weather event occurrences and earthquake with its impact.

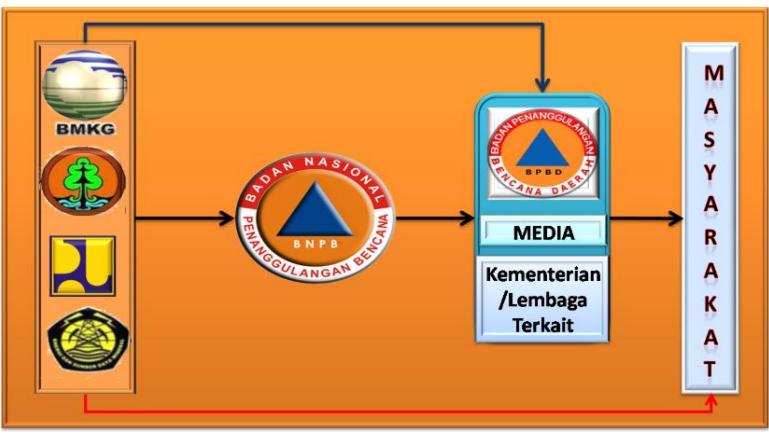

Fig. 2. The existing framework early warning system in Indonesia. Source : BNPB [19]

\subsection{Proposed framework of EWS for the Upper Bekasi river basin}

As shown in Fig 2, the scheme is applicable at the national level. At the regional level, particularly, the roles of BNPB are mandated to the provincial level of risk disaster management or BPBD. Because the Upper Bekasi watershed is located in West Java (Jawa Barat), the responsible regional authority is BPBD Jawa Barat. In terms of torrential rain that induces flooding in the watershed, other institutions that do not relate directly are excluded.

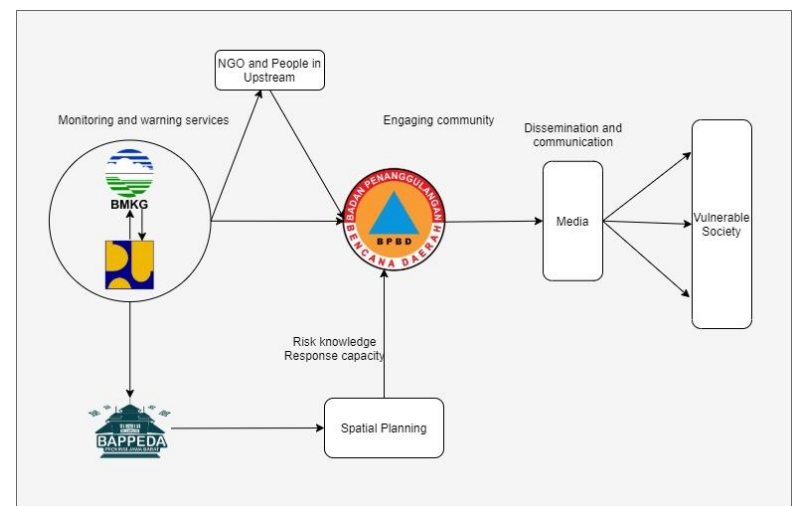

Fig. 3. The proposed EWS Framework in Upper Bekasi Watershed
As for the responsibility of BMKG, extreme weather events are 24-hours observed, and simultaneously the nowcasting of those events is produced. In 2015, however, WMO promulgated shift paradigms towards impact-based forecast and riskbased warning. The forecasting and warning should envelop not only what weather might be but also what weather might do [26]. Therefore, a robust partnership between BMKG and hydrological services (in Indonesia is represented by PUSAIR from Minister of Public Works and Human Settlements) to generate impactbased forecasts and risk-based warnings. Thus, the primary actors for monitoring and warning services are BMKG and PUSAIR. In Fig. 2, the framework is mostly a top-down-approach. However, engaging communities as bottom-up approach can improve the whole system to the preparedness of the beneficiaries [27]. Engaging communities, particularly in upstream, and NonGovernmental Organization (NGO) that care for the watershed will enhance the effectiveness of EWS. The engaged communities can participate not only in the monitoring and warning parts by observing the water level of the river but also give aid for disseminating the warnings.

BMKG, PUSAIR, and the regional planning board in Jawa Barat (Bappeda Jabar) also need to strengthen their partnerships. Heavy rain and flood risk mapping for increasing risk knowledge required the resources from BMKG and PUSAIR, hence, Bappeda Jabar can create better spatial planning. The spatial planning also is recommended to BPBD Jawa Barat to position safety shelters and escape routes when flooding occurs. If the shelters are settled, enhancing response capability by providing education and simulation can also be done. To broadening the network and ensure vulnerable societies are reached, all institutions are suggested to embrace all possible media ranging from televisions, radios, and remarkably, social media.

\section{Discussion}

A state-of-the-art hydro-meteorological modelling WRF-Hydro is a prospective tool to enhance flood forecasting. The results of the WRF-Hydro employment have been reassuring users since it was introducing. For instance, Wehbe et al. [25] showed that WRF-Hydro reduced the RMSE and biases by $24 \%$ and $13 \%$, respectively, in forecasting precipitation compare to the conventional WRF. Another example is the study conducted by Naabil et al [24] that employed WRFHydro to simulate discharge. The research resulted in remarkably feasible 0.78 and 0.89 of Nash-Sutcliff efficiency (NSE) and Pearson's correlation corresponded to observation, respectively. These results highlighted that WRF-Hydro is a recommended instrument that can be operationally employed for flood forecasting since it provenly lessened biases and generated high values of correlation that indicated better performance of NWP. Notwithstanding its imperfection because of underestimating discharge, WRF-Hydro successfully lessened biases, accurately produced hydrological and meteorological attributes, and 
spawned decorous rain and streamflow simulations. Regardless of the improvement of accurate and timely weather forecasts, people-centred EWS prerequisites other vital elements. Therefore, this study presented a framework that could be optimizing other essential components of an EWS. However, some challenges persist to achieve this framework.

Albeit WRF-Hydro has been being employed globally since recent years to estimate rainfall and discharge, the implementation of WRF-Hydro in tropical archipelagic countries like Indonesia is worth studying, particularly to examine the capability of WRFHydro in tropical watersheds. However, several challenges to implementing the finding of this study exist. Firstly, we will discuss the challenges of WRFHydro employment in Indonesia. The weather condition of Indonesia will be the first challenge because weather conditions vary vastly in IMC due to topographic profiles and sea surface temperature induction [28]. Moreover, the second challenge of the employment of WRF-Hydro is the requirement of highly computerbased and physics skills. WRF-Hydro is an example of interdisciplinary instruments because it demands the collaboration of hydrology and meteorology to optimize the output of WRF-Hydro. Secondly, to produce an effective EWS, the proposed framework is challenged by some factors. Initially, partnerships between institutional governments, private sectors, and communities that are obliged will confront the political priority of each stakeholder. Commonly, political priorities hinder and slower decision making. Zhang et al. [29], notably, also mentioned that the central governments of developing countries such as Indonesia have been struggling with mitigation financial so that it is strenuous to delimit the most vulnerable communities from official forecasts. Besides that, the dissemination and communication element of an effective EWS will remarkably depend on networks. Frequently, when extreme rain pours, suddenly connection will get worsen. On top of that, Otto et al. [30] emphasized the urgency of understanding more about social sciences to address challenges of the risk communication process in which profoundly contingent on the beneficiary's psychology, knowledge, skills, and capabilities. Therefore, interdisciplinary team should be established to build an effective EWS.

Enhancing severe weather early warning systems in the Upper Bekasi river basin is essential so that governments, communities, and private sectors can reduce the risk of flooding. Therefore, studies on the employment of WRF-Hydro is urgently required to generate accurate flood forecasting in a timely manner. On top of that, interdisciplinary knowledge and partnership also indispensably essential to secure effective early warning systems. Combining these will hopefully thrive sustainability and improve community resilience.

\section{Conclusion}

To conclude, according to article reviews, those articles indicated that WRF-Hydro is a beneficial tool that most parts of the world utilised for flood forecasting. Besides, WRF-Hydro also can be used for multiple purposes such as estimating water balances, managing water resources, analysing severe weather conditions, evaluating regional water and energy cycle, and reconstructing streamflow. Furthermore, optimally employing WRF-Hydro to produce more accurate predictions in tropical climatic regions, establishing an effective EWS to minimize loss and damage due to flooding are essentially requisite. However, there should be more studies to overcome the challenges in employing WRF-Hydro and constructing interdisciplinary teams to implement the proposed effective EWS. Hence, institutional governments that have primary roles such as BNPB, BMKG, PUSAIR, and Bappeda Jabar should collaborate more and engage other stakeholders to actualise this framework. Sanguinely, implementing the four main principles of an effective EWS in the proposed EWS framework will enhance the flood preparedness in the Upper Bekasi watershed and might be applicable in other regions.

\section{Acknowledgment}

The authors gratefully thank the Ministry of National Development Planning, BMKG, and ESRI for the substantial support.

\section{References}

1. S. N. Jonkman, "Global Perspectives on Loss of Human Life Caused by Floods," Nat. Hazards, vol. 34, no. 2, pp. 151-175 (2005)

2. D. (IFRC) Fisher, K. (IFRC) Hagon, C. Lattimer, S. O'Callaghan, S. Swithern, and L. Walmsley, World Disasters Report 2018. Leaving No One Behind: The International Humanitarian Sector Must Do More to Respond to the Needs of the World's Most Vulnerable People. Geneva: International Federation of Red Cross and Red Crescent Societies (2018)

3. M. D. Yamanaka, "Physical climatology of Indonesian maritime continent: An outline to comprehend observational studies," Atmos. Res., vol. 178-179, pp. 231-259 (2016)

4. Badan Nasional Penanggulangan Bencana (BNPB), "Infografis Update Data BencanaTgl. 26 Maret 2020 Pkl. 10.00 WIB" (2020) [Online]. Available: https://bnpb.go.id/infografis/infografisupdate-data-bencana-tgl-26-maret-2020-pkl-1000-wib. [Accessed: 15-Apr-2020].

5. BNPB, "Bencana Alam Di Indonesia Tahun 2010 s/d 2020” (2020) [Online]. Available: http://bnpb.cloud/dibi/tabel1a. [Accessed: 20-Apr2020].

6. Y. Hirabayashi et al., "Global flood risk under climate change," Nat. Clim. Chang., vol. 3, no. 9, pp. 816-821 (2013)

7. Y. Budiyono, J. Aerts, J. J. Brinkman, M. A. Marfai, and P. Ward, "Flood risk assessment for 
delta mega-cities: a case study of Jakarta," Nat. Hazards, vol. 75, no. 1, pp. 389-413 (2015)

8. R. S. van Voorst, "Get ready for the flood! Riskhandling styles in Jakarta, Indonesia," University of Amsterdam (2014)

9. T. Kadri and E. Kurniyaningrum, "Impact Of Land Use On Frequency Of Floods In Upper Bekasi Watershed, Indonesia," Int. J. Sci. Technol. Res., vol. 8, no. 12, pp. 3328-3334 (2019)

10. A. Rojali and P. Elsari, "Pemodelan Banjir di Perumahan Pondok Gede Permai Bekasi," Rekayasa Sipil, vol. 9, no. 1, p. 6 (2020)

11. BNPB, "Geoportal Kebencanaan Indonesia," (2020) [Online]. Available: https://gis.bnpb.go.id/. [Accessed: 01-Oct-2020].

12. UNISDR, "Developing Early Warning Systems : A Checklist," Third Int. Conf. Early Warn., no. March, pp. 1-13 (2006)

13. World Meteorological Organization, Guidelines on Early Warning Systems and Application of Nowcasting and Warning Operations. Geneva: WMO (2010)

14. World Meteorological Organization (WMO), "Flood Forecasting and Early Warning," Integr. Flood Manag. Tools Ser., no. 19, p. 59 (2013)

15. J. G. Powers et al., "The Weather Research And Forecasting Model Overview, System Efforts, and Future Directions," Bull. Am. Meteorol. Soc., no. August, pp. 1717-1738 (2017)

16. J. Li, Y. Chen, H. Wang, J. Qin, J. Li, and S. Chiao, "Extending flood forecasting lead time in a large watershed by coupling WRF QPF with a distributed hydrological model," Hydrol. Earth Syst. Sci., vol. 21, no. 2, pp. 1279-1294 (2017)

17. A. Senatore, G. Mendicino, D. J. Gochis, W. Yu, D. N. Yates, and H. Kunstmann, "Fully coupled atmosphere-hydrology simulations for the central Mediterranean: Impact of enhanced hydrological parameterization for short and long time scales," J. Adv. Model. Earth Syst., vol. 7, no. 4, pp. 16931715 (2015)

18. M. Sun et al., "Evaluation of Flood Prediction Capability of the WRF-Hydro Model Based on Multiple Forcing Scenarios," Water, vol. 12, no. 3, p. 23 (2020)

19. Badan Nasional Penanggulangan Bencana, "Pedoman Sistem Peringatan Dini Berbasis Masyarakat" (2012)

20. D. Gochis, W. Yu, and D. Yates, The NCAR WRFHydro Technical Description and User' s Guide Version 1.0 (2013)

21. A. Sullivan and D. D. White, "An Assessment of Public Perceptions of Climate Change Risk in Three Western U.S. Cities," Weather. Clim. Soc., vol. 11, no. 2, pp. 449-463 (2019)

22. W. F. Krajewski et al., "Real-time flood forecasting and information system for the state of Iowa," Bull. Am. Meteorol. Soc., vol. 98, no. 3, pp. 539-554 (2017)
23. D. J. Gochis, W. Yu, and D. N. Yates, "The WRFHydro model technical description and user's guide, version 3.0," NCAR Tech. Doc., no. May, p. 120 (2015)

24. E. Naabil, B. L. Lamptey, J. Arnault, H. Kunstmann, and A. Olufayo, "Water resources management using the WRF-Hydro modelling system: Case-study of the Tono dam in West Africa," J. Hydrol. Reg. Stud., vol. 12, no. June, pp. 196-209 (2017)

25. Y. Wehbe et al., "Analysis of an Extreme Weather Event in a Hyper Arid Region Using WRF-Hydro Coupling, Station, and Satellite data," Nat. Hazards Earth Syst. Sci. Discuss., no. September, pp. 1-34 (2018)

26. WMO, WMO Guidelines on Multi-hazard Impactbased Forecast and Warning Services, no. 1150. Geneva: World Meteorological Organization (2015)

27. V. Tarchiani et al., "Community and impact based early warning system for flood risk preparedness: The experience of the Sirba river in Niger," Sustain., vol. 12, no. 5, p. 24 (2020)

28. E. Aldrian and R. D. Susanto, "Identification of three dominant rainfall regions within Indonesia and their relationship to sea surface," Int. J. Climatol., vol. 1452, pp. 1435-1452 (2003)

29. X. Zhang, Q. Zhong, R. Zhang, and M. Zhang, "People-centered early warning systems in China: A bibliometric analysis of policy documents," Int J. Disaster Risk Reduct., vol. 51, no. June, p. 101877 (2020)

30. P. Otto, A. Mehta, and B. Liu, "Mind The Gap: Towards and Beyond Impact Messaging to Enhance Tropical Cyclone Risk Communication," Trop. Cyclone Res. Rev., vol. 7, no. 2, pp. 140-151 (2018) 